\title{
O SIGNO: LUGAR DE ENCONTRO DA SEMIÓTICA E DA FILOSOFÍA ANALÍTICA. DIFERENZAS E CONSECUENCIAS DOS MODELOS DE ANÁLISE DIÁDICO E TRIÁDICO DO SIGNO
}

\author{
Ma Uxía Rivas MonRoy \\ Universidade de Santiago de Compostela \\ http://dx.doi.org/10.15304/ag.39.1.6339
}

\section{Introdución}

Un dos obxectivos que guía este escrito é o de establecer que tanto dende a Semiótica como dende a Filosofía Analítica, en especial, dende as orixes de ambas as dúas, a análise e a reflexión sobre a noción de signo foi fundamental para os autores fundadores destas correntes de pensamento, pero tamén para os seus continuadores, en consonancia co xiro lingüístico que estaba a tomar a filosofía. En xeral, nas teorías da representación sígnica, tanto da Semiótica como da Filosofía Analítica, poden distinguirse dous modelos de análise do signo, a saber, o modelo diádico, centrado na relación vehículo sígnico / significado, e o modelo triádico, que pon en xogo un terceiro elemento, o obxecto, ao cal o signo se refire.

O modelo diádico da representación sígnica, no que destaca a relación significante / significado, foi establecido polo lingüista xinebrino Ferdinand de Saussure, o fundador en Europa da semioloxía, denominación que propuxo ao establecer a necesidade de que existira unha ciencia xeral do signo, que englobara á lingüística. Este modelo diádico foi seguido polo semiótico italiano Umberto Eco, o cal considerou que un programa satisfactorio para 
o desenvolvemento teórico da semiótica sería a elaboración dunha teoría da mentira. O modelo diádico de análise do signo proposto por Saussure caracterízase por subliñar que a relación sígnica fundamental é a que se establece entre significante e significado - en terminoloxía deste autor-e poñer en primeiro plano e como trazo fundamental do signo o seu carácter arbitrario, mentres que realiza unha exclusión do obxecto en favor do sistema. O modelo triádico do signo, pola contra, ten en consideración un terceiro elemento, a saber, o obxecto, xa que a perspectiva de análise que aquí interesa é, por un lado, a explicación filosófica da función epistémica do signo e, por outro, a dimensión referencial dos signos e para iso é necesaria a inclusión do obxecto. As reflexións sobre o signo realizadas por Gottlob Frege, un dos iniciadores da Filosofía Analítica, e por Charles S. Peirce, o fundador norteamericano da semiótica, axustáronse a un modelo triádico, onde o papel asignado ao obxecto como elemento causal xerador do sentido ou o significado era inescusable. Na Filosofía Analítica tamén hai modelos de análise do signo diádico, como o proposto por Bertrand Russell ou Saul Kripke, relativos a expresións directamente referenciais como nomes propios ou deícticos, pero a diferenza dos modelos diádicos da análise semiótica, aquí a relación básica establecida non é entre vehículo sígnico e sentido, senón entre vehículo sígnico e obxecto, constituíndo este último todo o significado que un signo pode transmitir, primando, polo tanto, a relación signo / obxecto.

Outro dos obxectivos que se pretende con estas páxinas é presentar as consecuencias que se seguen a partir destes dous modelos de análise do signo, dependendo do lugar e o papel que, como xa se indicou, se concede a un dos elementos — presente ou ausente- nesta análise e que non é outro que o obxecto, entendido este último dende unha ampla consideración. Dende a Filosofía Analítica, algúns dos seus máis insignes representantes centráronse neste elemento e as súas variantes (particulares, feitos, estados de cousas, etc.), porque a dimensión referencial dos signos é fundamental para determinar o valor de verdade dos enunciados, e este - o valor veritativo- é esencial nos estudos e análises da función da linguaxe como sistema de coñecemento e, máis precisamente, como sistema no que se expresa o coñecemento científico; así autores como Frege, Russell ou o Wittgenstein do Tractatus, pero tamén autores máis actuais como Donald Davidson, centráronse nesta perspectiva extensional na análise do signo e da linguaxe, coa cal a outra dimensión igualmente importante dos signos, a saber, a do seu sentido ou significado, foi relegada a ocupar un lugar secundario, aínda que non por iso se deixou de ter en consideración. 


\section{O modelo diádico do signo: a exclusión do obxecto}

Neste apartado presentarase o modelo diádico do signo que foi tomado como punto de partida por moitos semióticos a partir das consideracións que sobre o signo realizara Saussure e que despois desenvolveu Eco, propoñendo a denominación de "función semiótica" fronte a máis usual de signo. De Saussure destacarase como a determinación do significado do signo lingüístico faise tomando como referencia o sistema ou lingua, para o cal introduce a noción de valor. En ningún caso, neste modelo de análise está presente o obxecto. Eco, pola súa parte, é máis radical e explícito con respecto ás consecuencias de asumir este modelo diádico e de excluír do mesmo ao obxecto, ao indicar que entender o signo en termos referenciais ou extensionais nos privaría dunha auténtica comprensión do que é un signo ou unha función semiótica, e analizalo neses termos na teoría dos códigos ou semiótica da significación - a parte da semiótica que, na distinción de Eco, se ocupa de establecer as condicións que fan que un signo sexa tal-é cometer a falacia referencial ou a falacia extensional.

\subsection{O modelo diádico de Saussure. A importancia da arbitrariedade do} signo e da noción de valor

Un dos trazos fundamentais que caracterizan aos signos lingüísticos e que foi posta de relevo por Saussure é a relación de arbitrariedade que se dá entre os dous elementos que conforman o signo lingüístico, a saber, o significante e o significado, tal e como Saussure denominou ao que previamente considerou que era a imaxe acústica e o concepto, respectivamente. Como lingüista, Saussure destacou o interese de estudar á imaxe acústica ou significante, pois este era o elemento "material" do signo, e ao que unha parte da lingüística, a fonética e tamén a fonoloxía, prestaban a súa atención. En relación co concepto ou significado, os seus comentarios, presentados na súa obra póstuma O curso de lingüística xeral (1916), non foron moi abundantes, dando por suposto que o concepto viña a coincidir cos "feitos de conciencia". No que si reparou Saussure e sinalou como unha das propiedades esenciais do signo foi a súa arbitrariedade, arbitrariedade que entendía como a relación non natural, isto é, non motivada, que se establecía

1 “Material” en oposición ao significado, que é máis abstracto, xa que o significante, como imaxe acústica, representa a pegada que o son, que si é material, deixa na mente dos falantes (cfr. Saussure, Curso de lingüística general, 1980, p. 102). Hai que ter en conta que para Saussure o signo lingüístico era de natureza psíquica, natureza aplicable, por conseguinte, tanto ao significante como ao significado que o constitúen (cfr., ibid., p. 38). 
entre o significante e o significado, por iso, o signo lingüístico, entendido como a asociación de significante e significado, era arbitrario. A asociación entre significante e significado tiña lugar en cada acto de fala particular no cerebro dos individuos que se comunicaban, pero estas asociacións estaban xa ratificadas polas convencións sociais. $\mathrm{O}$ aspecto social da lingua e o seu establecemento a través de acordos ou convencións, que a vontade individual non pode cambiar, é un dos que con máis frecuencia aparecen no Curso de lingüística xeral. Saussure consideraba, pois, que a lingua era un produto social, froito de convencións, creado pola colectividade e a presentaba como unha especie de contrato establecido polos membros da comunidade, pero que, a diferenza das outras institucións, non se pode cambiar á vontade dos individuos. Pero tamén, na súa opinión, entender a lingua como facultade de asociación e coordinación entre significante e significado, levaba implícito prestar atención a dimensión da lingua como sistema, como principio organizador das unidades que produce.

Así pois, e en relación con esta concepción da lingua como sistema, aínda que Saussure non proporcionou unha explicación precisa do que era exactamente o significado, si que tivo o mérito de introducir unha noción importantísima para explicar como os significados, ao igual que os significantes, son producidos polo sistema. Esta noción, que dá conta da constitución dos signos nos seus propios termos e sen introducir nada alleo ao sistema que os xera, que non é outro que a lingua, foi a de valor lingüístico, noción que se complementa coa idea saussureana de que a lingua é unha forma e non unha sustancia. Entender a lingua como un sistema de signos distintos que expresan ideas distintas implica unha dimensión organizativa e relacional dos signos, caracterizada polo valor diferencial e negativo dos elementos que a constitúen como tal. A lingua como conxunto de elementos, como sistema, só pode comprenderse atendendo á idea de valor. A noción de valor lingüístico deriva da caracterización que o propio Saussure ofrece da determinación do valor, e que ten dous trazos fundamentais. Un deles é a comparación: para poder determinar o valor dun elemento precisamos comparalo con aquilo que se lle asemella, e cuxo valor aínda está por determinar; Saussure pon o exemplo dunha moeda de 5 francos, que se pode comparar con unidades maiores ou menores, e así pode determinarse o seu valor. Se pensamos na nosa moeda, vemos que un euro pode compararse con dúas moedas de 50 céntimos, ou mesmo con outras moedas, como o dólar, determinando que un euro son 1.12 dólares, segundo o mercado de divisas. Pero para que a determinación do valor sexa completa é preciso tamén saber por que cousa desemellante se pode cambiar, así un euro pode 
cambiarse por unha barra de pan ou un litro de leite, un bolígrafo ou un caderno de notas. Con estas dúas dimensións determinadas, determínase, entón, o valor. No caso da lingua, para establecer o valor dun significante ou dun significado é preciso que tanto un como o outro se poidan comparar con significantes ou significados semellantes, máis tamén que se poidan cambiar por algo desemellante, neste caso, un significante se cambiaría por un significado e viceversa.

A determinación do valor na lingua ten unha peculiaridade moi especial. $\mathrm{Na}$ lingua, di Saussure, todo é negativo e diferencial, é dicir, tanto os significantes como os significados son negativos, caracterízanse por ser o que os outros non son, por ocupar unha posición que os demais non ocupan, e ese lugar definido en termos negativos, relacionais ou diferenciais é o que lle dá o valor aos compoñentes do signo. Aquí, polo tanto, non podemos falar en termos positivos, non hai significante ou significado previamente dado, nin signo preexistente ao sistema. Pensar en termos positivos é caer no erro de considerar á lingua unha nomenclatura, a cal non produce nin xera as súas unidades, senón que simplemente produce asociacións de elementos xa previamente dados, a saber, os significados e os significantes preexistentes ao sistema. A lingua, pola contra, consiste na produción dos seus elementos, os signos, atendendo unicamente á súa posición no sistema e as relacións entre os elementos que configuran os signos, isto é, os significantes e os significados. Non se require nada externo á propia lingua, son os seus elementos e as posicións que ocupan os que lle fan adquirir un valor, valor que é negativo e diferencial: ser o que os outros non son. En cambio, o signo na súa totalidade, como configuración de significante e significado, é para Saussure un feito positivo. Pero este feito positivo só pode entenderse por relación ao valor que xerou o sistema, onde non hai signos dados previamente, senón significantes e significados que adquiren o seu valor polas súas posicións no conxunto do sistema, pois é a lingua como estrutura ou como forma, a que recorta e establece as unidades, as cales, por estar onde están e ocupar o lugar que os demais non ocupan, adquiren un valor, definido simplemente nestes termos negativos e relacionais, sen recorrer a nada alleo ao propio sistema que as produce.

Deste xeito, no modelo de Saussure a produción de significado deriva directamente do sistema e do valor que o sistema outorga aos seus elementos en función da súa posición e relación no mesmo. Este modelo diádico de explicación do signo, remite directamente ao sistema para poder determinar a constitución dos significantes e significados que dan lugar aos signos. O papel do obxecto nin sequera é mencionado, e a referencia ao mesmo 
non é precisa para explicar como se xera o signo no sistema. Pártese da idea de que os significados se determinan polas súas relacións opositivas e diferenciais no sistema e que é o propio sistema, como forma, o que establece as relacións arbitrarias entre estes e os significantes. Por esta razón, a propiedade fundamental do signo para Saussure era a súa arbitrariedade, pois esta é a garantía de que a asociación entre significante e significado que dá lugar ao signo xurde do propio sistema e das relacións de oposoción dos significantes e significados entre si; as relacións motivadas, propias do que el denominou "símbolo", daban lugar a ambigüidades, que facían dubidar que un símbolo fora realmente un signo, pola coincidencia que se establecía entre significante e significado.

\subsection{O modelo diádico de Eco. O signo como función semiótica e o sig- nificado como unidade cultural}

Eco, xa dende o comezo da súa traxectoria intelectual, intentou descartar o papel protagonista do obxecto na análise do signo, para así conseguir unha comprensión máis ampla e efectiva do que é e constitúe realmente un signo. Dende o seu punto de vista, enmarcado na semiótica, entendida esta baixo o marco social estipulado por Saussure ${ }^{2}$ como a ciencia que estuda os signos en todas as súas dimensións e nas súas implicacións sociais e culturais, Eco propón, como xa se indicou, que un dos obxectivos da semiótica sería implicarse na elaboración dunha teoría da mentira, a cal se abordaría dende a consideración do signo como unidade semántica-cultural.

Segundo manifesta en numerosas ocasións Eco, para que algo sexa signo ten que ter a capacidade ou a posibilidade de mentir. Este é, en realidade, o seu criterio para distinguir un signo de algo que non o é. O que é é e, como tal, non ten posibilidade de ser usado para mentir. Se algo é signo ten que ter a capacidade de poder dicir o que non é. Para Eco, ao igual que xa apuntara anteriormente Saussure no seu Curso de lingüística xeral, a noción de signo resulta pouco satisfactoria ${ }^{3}$, xa que tende a identificarse con só unha das partes que constitúen o signo, a saber, esa parte "material" que Saussure chamou o significante, precisamente por ser esta unha imaxe

${ }^{2}$ A definición de Saussure é a seguinte, tal e como se recolle no Curso de linguística general: "Puede por tanto concebirse una ciencia que estudie la vida de los signos en el seno de la vida social; formaría parte de la psicología social, y, por consiguiente, de la psicología general; la denominaremos semiología (del griego sémeîon, "signo")", op. cit., pp. 42-43.

${ }^{3}$ Así o manifestaba Saussure: "En cuanto a signo, si nos contentamos con ese término es porque, al no sugerirnos la lengua usual ningún otro, no sabemos por cuál reemplazarlo", ibid., p. 104. 
acústica do son, e por iso no seu Tratado de semiótica xeral Eco propón como noción substitutiva da de signo a de función semiótica. Esta nova denominación da noción tradicional de signo é a que lle permite a Eco sustentar esa concepción do signo como aquilo que ten a capacidade de mentir, xa que a función semiótica non é unha entidade simple, senón un complexo formado por elementos procedentes de dous planos de distinta natureza, a saber, o plano da expresión e o plano do contido, e que son parcialmente asimilables, respectivamente, aos termos de "significante" e "significado" propostos por Saussure. O signo é, baixo esta consideración, unha relación entre elementos destes dous planos, é, por conseguinte, unha función, no sentido matemático do termo, e os elementos que o conforman son denominados por Eco "funtivos". Os funtivos do plano da expresión configuran a parte física do signo, a cal é perceptible por algún dos sentidos, mentres que os funtivos do plano do sentido son abstractos, comprensibles de xeito intelectual ou racional, e Eco denomínaos "unidades culturais", o que, en terminoloxía máis tradicional e familiar, viría a ser asimilable ao sentido, ao significado ou á significación propia dun signo.

Baixo esta interpretación, o signo ou función semiótica é unha presenza - a parte perceptible correspondente ao plano da expresión- que remite ou reenvía a unha ausencia -a parte abstracta, non perceptible a través dos sentidos, correspondente ao plano do sentido. E é, xustamente, este elemento ausente ao que o signo remite o que fai posible que o signo poida ser usado para mentir, xa que se algo non se percibe ou non está á vista, sempre é posible dicir diso o que non é, ao deformalo, transformalo, ocultalo ou, mesmo, negarlle a existencia. Mais este cadro non estaría completo, se non se introduce nel a relación convencional e arbitraria que vincula estes dous elementos conformadores do signo, esa relación coñecida polas usuarias e usuarios de signos ou aquelas e aqueles que dominan unha lingua ou un sistema de representación. Esa relación que fai que, en ausencia dunha realidade dada, poidan empregarse os signos para describila e facela mediatamente ${ }^{4}$ presente, mais tamén para transformala, cambiala, modificala, negala ou mesmo inventala. Precisamente porque as usuarias e usuarios de signos coñecen que un significante remite a un significado, ou tamén a un referente, poden facer uso dos signos para mentir.

${ }^{4}$ Morris considera que esta é a característica mais importante do proceso de semiose, isto é, o proceso no que algo funciona como signo, ao afirmar: "Por tanto, en la semiosis algo toma en consideración otro algo mediatamente, es decir, a través de un tercer algo. La semiosis es, en consecuencia, una consideración mediada" (C. Morris, Fundamentos de la teoría de los signos, p. 28). 
Unha aclaración significativa neste momento é a de non caer na tentación de tomar a parte polo todo. O feito de que Eco destaque na súa proposta a dimensión posibilística e creativa que os signos nos abren, non debe facernos perder de vista que un dos usos fundamentais dos signos é o de dicir a verdade, ou o de presentar ou re-presentar o que é. Pero aquel outro uso do signo tan relevante para Eco, a saber, o de dicir o que non é verdade, o de mentir nese sentido amplo que inclúe a deformación, a manipulación ou a invención, é para outros propósitos tamén fundamental, especialmente para dar renda solta á nosa imaxinación, á nosa fantasía, á nosa necesidade vital de superar e ir más alá do que a realidade e o mundo nos ofrecen; é, pois, este uso dos signos un uso básico para a nosa ansia de crear e inventar, de contemplar e estudar as posibilidades, de recreármonos en mundos posibles que amplíen o limitado horizonte da realidade cotiá na que diariamente estamos inmersos. Este aspecto esencial da nosa humanidade é indisociable da nosa natureza lingüística e representativa, e da potenciación exponencial da imaxinación vinculada a ela. Dende os pobos primitivos que contan historias e mitos, ata as primeiras grandes obras épicas da historia occidental como A Ilíada e A Odisea, chegando aos nosos días de Internet e os medios masivos de comunicación, a invención, a imaxinación e a creación é non só unha constante que é inseparable da nosa natureza curiosa, inquieta, inconformista e creativa, senón tamén inseparable do noso uso de signos e sistemas de representación.

Para Eco, a inclusión do obxecto na súa proposta de análise do signo ou, como el prefire denominalo, función semiótica non xoga ningún papel semioticamente relevante para chegar a comprender o trazo máis distintivo do signo ao que anteriormente se apuntou, isto é, a súa capacidade de poder ser usado para mentir; máis ben ao contrario, incluír no modelo de análise do signo ao obxecto só pode proporcionar unha visión limitadora e reducionista das amplas potencialidades semióticas que os signos teñen. Por iso, e seguindo de cerca a proposta de Roland Barthes, que introduciu no seu texto Elementos de semioloxía as nocións vinculadas ao significado de denotación e connotación, Eco suxire desvincular a noción de denotación do seu uso característico na Filosofía Analítica como sinónimo de referencia ou referente, para vinculalo ao que sería o contido ou significado, ou ao que el denominou máis tarde "unidade cultural". Tal e como xa indicaba na Estrutura ausente, un dos seus propósitos era liberar ao termo "denotación” do seu compromiso histórico co referente ${ }^{5}$, de tal maneira que as

\footnotetext{
${ }^{5}$ Cfr. U. Eco, La estructura ausente, p. 83.
} 
expresións non van a denotar obxectos, senón unidades culturais, sendo a semiótica a ciencia que estuda os signos, entendidos estes como forzas sociais, relativos a convencións e códigos culturais. Polo tanto, o significado dunha expresión, entendido agora como a súa denotación, é unha unidade cultural, unha entidade abstracta que unha comunidade ou unha cultura define nos seus propios termos, e que, en ningún caso, debe identificarse co obxecto ou o referente dun termo. Deste xeito, a noción de denotación en Eco pasa a ser unha categoría intensional, relativa ao significado, fronte ao seu uso habitual na Filosofía Analítica como unha categoría referencial; así pois, a denotación para Eco é o contido da expresión, a primeira correlación significante establecida por un código cultural.

Dada a relevancia que esta reflexión en torno ao obxecto tivo no pensamento de Eco e os diferentes matices e posicións que o autor foi adoptando ao respecto, será interesante presentar, aínda que sexa rapidamente, o traxecto percorrido por el no seu intento de exclusión da semiótica do obxecto ou do referente, unha constante que se pode observar en moitas das súas obras. Porén, no Tratado de semiótica xeral Eco consegue resolver certa tensión creada por esta exclusión, ao impedir a referencia ao obxecto só na parte da semiótica que el denominou "semiótica da significación", pois introducir o obxecto neste ámbito orixina a falacia referencial e a falacia extensional. Desta forma farase visible o seu interese en recalcar, a partir de diferentes explicacións e argumentos, o que, dende o seu punto de vista, é esencial para caracterizar o signo, isto é, a súa capacidade de estar en lugar doutra cousa, o feito de ser unha presenza que remite a unha ausencia; é, precisamente, nese tránsito onde reside a auténtica potencialidade dos signos, aquela que lles permite non só dicir a verdade, senón tamén, crear, imaxinar, inventar, recrear mundos e situacións. A pretensión de Eco de excluír o obxecto ou referente na análise da noción de signo ten como finalidade destacar esa dimensión, ao seu modo de ver, máis esencial e característica do signo, que é aquela que vincula ao signo co seu significado ou comprensión, coas unidades culturais, determinadas e asumidas por unha cultura ou sociedade, e que permiten explicar a capacidade do signo de poder ser empregado para mentir nese sentido amplo do termo que inclúe a creación, a invención, a fantasía, a imaxinación.

$\mathrm{Na}$ Estrutura ausente, obra publicada orixinalmente en 1968, Eco xa sinalaba que a semiótica se ocupaba das "condicións de comunicabilidade e comprensibilidade da mensaxe" ${ }^{6}$ e que para este fin a apelación ao obxecto,

\footnotetext{
${ }^{6}$ Ibid., p. 79.
} 
como referente, non só non resultaba unha noción semioticamente inútil, senón ata perxudicial para comprender o funcionamento dun signo, tendo en conta os múltiples casos nos que os signos non refiren a obxectos. Aquí xa comezaba a establecer a diferenza, que logo tomaría como o eixo fundamental, entre esas condicións de comprensibilidade dos signos, que sería do que se ocuparía a semiótica, e as súas condicións de verdade, que serían o obxecto de estudo da lóxica, xa que estas últimas si que dependen da existencia do obxecto ou do referente. Desta forma, aínda que a apelación ao obxecto é importante para determinar as condicións de verdade dun enunciado, esta tarefa correspóndelle fundamentalmente á lóxica, e non permitiría, máis ben ao contrario limitaría, comprender en toda a súa amplitude o que é o significado dos signos. Así pois, nesta obra apúntase a que a unha das consecuencias da exclusión do obxecto na análise do signo sería que os enfoques que caracterizan a lóxica e semiótica se consideraran como dispares e sen relación entre si, pois mentres a semiótica se ocupa do significado ${ }^{7}$, a lóxica faino da referencia.

En Signo, unha obra de 1973, Eco segue na mesma liña argumental da Estrutura ausente, pois nela considera que os lóxicos son os responsables do que chamaba "a cuarta aparición do referente: o obxecto como denotatum do signo" e que consistía en introducir ao obxecto como un parámetro do propio signo. O problema que representa para a semiótica entender os signos dende a dimensión propia da lóxica referencial ou extensional é que vincularía directamente a noción de significado ao obxecto ou, como Eco indica nesta obra, á intuición empírica do referente, e, por conseguinte, a semiótica sería así incapaz de explicar que o significado dos signos remite sempre a convencións e acordos culturais, que en moitas ocasións están afastados da referencia empírica real aos obxectos, como se pon de manifesto na creación de mitos, contos, novelas, películas ou obras artísticas. É dicir, xa que nas linguas hai expresións para referirse a entidades ou obxectos non existentes, a perspectiva própria da lóxica extensional sería pouco axeitada para explicar o que caracteriza que algo poida considerarse como signo, pois só tería en conta a determinación dos valores veritativos dos enunciados a partir das referencias das súas expresións, pero non atendería á explicación dos seus significados como unidades culturais, con indepen-

${ }^{7}$ A. Domínguez Rey no seu libro Masaje del mensaje expresa esta misma opinión: "Eco demuestra en La Estructura ausente que la significación es en realidad el verdadero referente del signo, incluya o no el objeto designado", op. cit., p. 69.

${ }^{8}$ U. Eco, Signo, p. 148. 
dencia de se estas fan referencia a obxectos reais ou non. Esta oposición frontal á lóxica extensional está estreitamente vinculada tamén co obxectivo de que a semiótica debe ocuparse de establecer o que constitúe a un signo como tal e que, como xa se indicou, reside na súa capacidade de estar en lugar doutra cousa, de onde a súa capacidade máis xeral de mentir en sentido amplo. Se a explicación do que é un signo consistira só en estar en lugar doutra cousa real ou existente, entón esta mesma explicación non podería dar conta da dimensión creativa e imaxinativa que os signos posibilitan.

Tres anos despois da publicación de Signo, Eco escribe o Tratado de semiótica xeral, en 1976, obra definitiva e representativa da súa posición semiótica, e por iso advirte que, a partir deste momento, as críticas e comentarios relativos a temas semióticos deberán ter como punto de referencia esta obra e non obras súas anteriores a ela. Ademais, tamén indica que realizará críticas parciais a outras posturas súas, e entre elas se encontra un interesante cambio na consideración do obxecto ou o referente; se ata o momento a inclusión do obxecto como elemento necesario para abordar a natureza do signo lle parecía que non tiña suficiente capacidade explicativa, no Tratado de semiótica xeral Eco resolve a dificultade ocasionada pola exclusión absoluta do obxecto do tratamento semiótico ${ }^{9}$. Nesta obra divide a semiótica, dende o punto de vista da abordaxe teórica e metodolóxica, en dúas partes ben diferenciadas, a saber, a semiótica da significación ou teoría dos códigos e a semiótica da comunicación ou teoría da produción de signos. Incluír o obxecto ou referente na semiótica da significación é cometer a falacia referencial, relativa a termos singulares, ou a falacia extensional, relativa a aseveracións ou enunciados ${ }^{10}$; pero ter en conta aos obxectos, aos valores veritativos, ás referencias e ás extensións das expresións é totalmente lexítimo na semiótica da comunicación. Deste xeito resolve a tensión, que sempre estivo presente na súa obra, da non consideración do obxecto na explicación semiótica do signo. Eco segue mantendo que a mellor explicación do que é un signo ou unha función semiótica debe ser en termos semánticos-culturais, e debe realizarse na semiótica da significación. Así pois, e para manter a pureza teórica desta explicación coas categorías

${ }^{9}$ Así o indica ao afirmar que o Tratado de semiótica xeral "[i]ntenta introducir dentro del marco semiótico una teoría del referente que antes me había creído obligado a suprimir por razones de pureza teórica." (U. Eco, Tratado de semiótica general, p. 17).

${ }^{10}$ A falacia referencial consiste en considerar que o significado dun significante está relacionado co obxecto, mentres que a falacia extensional se comete cando se considera que a extensión, isto é, os valores veritativos dun enunciado, é unha categoría propia da semiótica da significación. Cfr. Ibid., pp. 123-125. 
propias da significación, tales como unidade cultural, sema, denotación, interpretante, etc., o obxecto non debe ser tido en conta na semiótica da significación. Pero na semiótica da comunicación — que se ocupa de estudar situacións comunicativas concretas, nas que efectivamente se levan a cabo referencias directas a obxectos, feitos, estados de cousas- introducir o referente, os valores de verdade, etc., é totalmente pertinente e lexítimo, pois xa non se ve como un problema que os signos fagan referencia a obxectos ou feitos. Polo tanto, entender o significado apelando ao obxecto só resulta incorrecto dende a semiótica da significación, pero non sucede o mesmo dende a semiótica da comunicación, que estuda precisamente a referencia das expresións a obxectos e situacións. En definitiva, o obxecto xa non vai ser totalmente excluído do campo semiótico, pois pode ser agora abordado semioticamente dende a semiótica da comunicación.

Eco recoñece no Tratado de semiótica xeral que ata entón o seu interese fundamental era construír unha semiótica intensional, sen ter en conta que os signos tamén se usan para referirse a estados de cousas ou cousas ${ }^{11}$, precisamente a teoría da mención ou a teoría da referencia, pertencentes á semiótica da comunicación, se ocuparían de analizar este uso dos signos. Porén, a alusión á metafísica do referente segue a estar presente tamén nesta obra, cando se introduce o obxecto ou o referente como categoría propia da semiótica da significación, xa que o que máis lle interesa a Eco é vincular a significación con fenómenos culturais e non exclusivamente referenciais ${ }^{12}$. E mesmo para reforzar esta idea de que o significado debe entenderse como unidade cultural e non referencial afirma que "a semiótica non é só a teoría de calquera cousa que sirva para mentir, senón tamén de calquera cousa que poida usarse para facer rir ou para inquietar" ${ }^{13}$. Así queda aínda máis claro por que a semántica extensional, de cuxo estudo se encarga a lóxica, non pode explicar o significado, xa que falta nela a referencia ao contexto cultural que produce os signos a través dos acordos e das convencións específicas de cada sociedade. As ironías, as bromas, os xogos de palabras, os disparates, os absurdos son comprensibles en cada comunidade lingüística e a semiótica da significación está en condicións de abordalos e explicalos, precisamente por entender o significado como unha unidade cultural. A semántica extensional, centrada nas condicións de verdade dos enunciados e nas extensións ou referencias dos mesmos, ou ben non se ocuparía destes

\footnotetext{
${ }^{11}$ Cfr., Ibid., p. 16.

${ }^{12}$ Cfr. Ibid., p. 123.

${ }^{13}$ Cfr. Ibid., pp. 126-127.
} 
fenómenos, por carecer de valor veritativo, ou ben os cualificaría de falsos, obviando deste xeito o estudo da relación cultural que dá lugar a estas alteracións de sentido que provocarían a risa ou o terror ${ }^{14}$.

\section{O modelo triádico do signo: a inclusión do obxecto}

O tema central deste apartado vai consistir en presentar os modelos triádicos de análise do signo, que inclúen ao obxecto como un elemento destacable para dar conta do fenómeno sígnico ou da representación ${ }^{15}$. Este modelo que inclúe tres elementos foi asumido tanto por Peirce, fundador da Semiótica, como por Frege, un dos inspiradores da Filosofía Analítica. Ambos os dous, lóxicos innovadores, destacaron a importancia que tiña a relación signo / obxecto. Frege sinalou explicitamente que a relación signo / sentido era fundamental para que algo puidera ser signo, pero esta relación diádica só amosaba un modelo de signo certamente incompleto e defectuoso; o modelo ideal de signo era aquel no que ademais do signo e o sentido se incluía o que el denominou "a referencia" —Bedeutung, en alemán-isto é, a entidade denotada polo signo. E así indicaba que nas linguaxes naturais era usual que houbera signos con sentido pero sen referencia, como era propio do uso da linguaxe para o cal a verdade non entraba en consideración. Pero nas linguaxes formais e científicas o modelo debería incluír necesariamente ao obxecto como referencia do signo, pois esta dimensión era esencial para as consideracións lóxicas, centradas nos valores de verdade

${ }^{14}$ As afirmacións de Eco neste sentido non deixan lugar á dúbida: “una semántica extensional no puede ayudar a una teoría de los códigos, dado que no resuelve el problema de la mentira y de la carcajada: hablando lógicamente, una mentira corresponde a una proposición Falsa y, por tanto, su contenido específico no es pertinente para los fines del cálculo: una proposición falsa puede ser cómica sin invalidar por ello la exactitud de la implicación...Explicar la importancia semiótica de una mentira significa comprender por qué y cómo es una mentira relevante semióticamente, independiente de la Verdad o Falsedad de la propia afirmación” (Ibid., p. 127).

${ }^{15}$ En semiótica é moi relevante o modelo triádico do signo de Morris, pero neste modelo o obxecto está incluído de xeito moi forzado como "denotatum", para poder dar conta da referencia dalgúns signos a obxectos realmente existentes. O modelo de Morris, cuxos elementos eran o vehículo sígnico, o designatum e o intérprete (as veces incluía tamén ao interpretante, pero sempre vinculado ao intérprete), foi o que levou á distinción máis coñecida da semiótica nas súas tres ramas de sintaxe, semántica e pragmática. O estudo do "denotatum" correspondíalle á semántica, aínda que a tarefa fundamental desta parte da semiótica era a análise das relacións entre o signo e o "designatum”, xa que a pragmática se ocupaba da relación dos signos cos seus intérpretes. Cfr. C. Morris, Fundamentos de la teoría de los signos, pp. 30-34. 
dos enunciados. Tamén Peirce sinalaba que o modelo que explicaba o proceso no que algo funcionaba como signo, o que el denominou "semiose", debería implicar sempre tres elementos, a saber, o signo ou representamen, o obxecto e o interpretante. Peirce entendía que a relación signo / obxecto era importante para a lóxica exacta — unha das partes nas que se dividía a semiótica, a ciencia que estuda as relacións de semiose-, mais para unha comprensión completa e total da semiose ou da representación sígnica, a semiótica debería abordar todos os elementos implicados no modelo de semiose e tamén as relacións que se establecen entre eles. Ademais, para el, ao igual que para Frege, a representación debe implicar sempre estes tres elementos para que teña lugar unha semiose xenuína.

A referencia ao obxecto nos modelos de análise do signo propostos por estes autores é absolutamente necesaria para poder explicar a función epistémica do signo. Aínda sen negar que a relación significante / significado é, claramente, arbitraria, tal e como afirmaba Saussure, tanto Frege como Peirce, actuando como filósofos, interesados, polo tanto, na explicación de onde lle vén ao signo a súa capacidade de transmitir coñecemento, elaboraron modelos explicativos nos que era imprescindible a inclusión do obxecto polo papel que este xogaba na representación. O obxecto cumpría a función de actuar como o elemento xerador que permitía establecer o significado dos signos, isto é, que permitía dar conta da capacidade que teñen os signos de presentar propiedades ou características dos obxectos; e estas características que presentan os signos a través do seu sentido ou significado non son arbitrarias, senón coincidentes con aquelas que teñen os obxectos aos que os signos se refiren. Os obxectos teñen propiedades e os signos as presentan a través do seu sentido ou significado, o que desta forma lles permite referirse a estes mesmos obxectos. Hai, por conseguinte, un dobre movemento necesario para explicar a capacidade cognoscitiva dos signos, xa que, por un lado, o signo ten un sentido ou significado, que non é arbitrario, senón que se establece pola relación co obxecto ao que o propio signo se refire, e, por outro lado, o signo refire a un obxecto, en moitas ocasións cando este non está presente, pola mediación que establece o seu sentido $^{16}$.

\footnotetext{
${ }^{16}$ Este modelo explicativo funciona especialmente para o tipo de expresións considerados termos singulares, que inclúen nomes propios en sentido ordinario, descricións definidas, deícticos, etc.
} 


\subsection{O modelo triádico de Frege. A importancia da referencia}

A análise do signo que presenta Frege é un paradigma do modelo triádico, pois tres son os elementos que entran en xogo nel, a saber, o signo, o sentido e a referencia. Estes elementos poderían facerse corresponder co plano lóxico ou formal da análise da linguaxe, co epistemolóxico e co ontolóxico, respectivamente. Para Frege, como xa se apuntou, a relación ideal consiste en que a un signo lle corresponda un sentido e a este unha referencia, aínda que isto non reflicte o comportamento usual da linguaxe, senón máis ben aquel que é desexable nunha linguaxe formal. A conexión que Frege establece entre estes tres elementos é moi clarificadora, por un lado, da complexidade que esconde unha noción tan usual e aparentemente comprensible como a de signo ou expresión, e, por outro, dos intereses que guiaron a propia distinción introducida por el. Por conseguinte, segundo Frege, a relación sígnica prototípica sería a seguinte: ao signo correspóndelle un sentido e a este unha referencia, mentres que á referencia non lle corresponde nin só un signo nin só un sentido, e o mesmo sucede co sentido, o cal pode ser expresado por diferentes signos. En opinión de Frege, o comportamento ideal da relación entre signo, sentido e referencia é o que hai que esixir nas linguaxes demostrativas e formais, como as matemáticas, mais nas linguaxes naturais é usual observar que a relación triádica se reduza á diádica signo / sentido, como o exemplifican nomes propios como 'Ulises' ou 'Pegaso', que teñen sentido pero non teñen referencia. Esta relación diádica é a relación semántica básica para que un signo poida selo, é dicir, un signo pode non ter referencia, pero en ningún caso un signo pode carecer de sentido. Poderíamos dicir que para que algo sexa signo é condición necesaria e suficiente que teña sentido, o cal é indicativo da importancia da dimensión semántica intensional fronte á extensional, no sentido reivindicado por Eco, tal e como se observou no apartado anterior.

Así pois, a relación semántica signo con sentido e referencia é prescindible nas linguaxes naturais, pero este non debería ser o caso das linguaxes científicas ou formais. Precisamente para Frege esta é a relación semántica máis importante, xa que como lóxico, o seu interese nas oracións da linguaxe centrábase naquelas que tiñan referencia, que no caso dos enunciados era para el un valor de verdade. De aí que destacara a dimensión semántica extensional fronte á intensional, a pesar de recoñecer que é esta última a fundamental para que algo poida ser considerado signo; pero nas linguaxes das ciencias demostrativas, e das ciencias en xeral, a prioridade invértese, e o esencial é garantir que o signo teña referencia; como resulta evidente, que un signo teña sentido é algo que xa ven implícito polo simple feito de 
ser signo. Para Frege, se unha oración contén un nome propio carente de referencia, entón carece ela mesma de referencia, isto é, de valor veritativo. En última instancia é unha oración que non interesa á lóxica, xa que non é nin verdadeira nin falsa; porén, non por iso deixa de ser unha oración da linguaxe, posto que é típico encontrar este tipo de oracións que só teñen sentido nas obras de teatro, as novelas, as fábulas, os contos, etc. Igualmente se o nome propio ten varios sentidos, como ocorre cos nomes propios ordinarios, estas "oscilacións de sentido", como as cualifica Frege, poden pasarse por alto sempre e cando a referencia da expresión siga sendo a mesma, outro exemplo máis da importancia da referencia para os obxectivos de Frege. Tanto é así que Frege denominou "Bedeutung” á referencia dos signos, dando a entender, como suxería Tugendhat ${ }^{17}$, que esta dimensión dos signos era para el a relevante, a significativa, a que tiña importancia ao analizar á linguaxe en relación coa lóxica e co coñecemento.

En resumo, Frege recoñece que a que el entende como tipo de "conducta normal" dos signos non sempre se dá na linguaxe ordinaria, onde é posible que para un sentido haxa distintas expresións e que unha expresión teña distintos sentidos, e mesmo que a un sentido non lle corresponda unha referencia. Na súa opinión, unha linguaxe perfecta non debe permitir este tipo de ambigüidades e as ciencias demostrativas, como as matemáticas ou a aritmética, deberían evitalas, non consentindo nin sequera expresións que presenten oscilacións de sentido. Polo tanto, a relación prioritaria para que algo puidera ser considerado signo era, como xa se sinalou, que este tivera sentido, pero a relación non defectiva era que ademais do sentido o signo tivera referencia; pero non só iso, senón que para ser perfecta a relación debería ser a seguinte: que a cada signo lle correspondera só un sentido e a este só unha referencia. Obviamente, esta esixencia só podía cumprirse nas linguaxes formais, pois nas linguaxes naturais, máis que a norma esta parecía ser a excepción.

Como filósofo da linguaxe, Frege estableceu unha ontoloxía, que proporcionaba as entidades que ían constituír as referencias dos signos. En principio, esta ontoloxía é moi simple, xa que conta unicamente con dous tipos de entidades: obxectos e funcións, saturadas ou completas as primeiras, insaturadas ou incompletas as segundas; as referencias das expresións completas eran obxectos e as referencias das expresións incompletas eran funcións. Polo tanto, todo o que hai ou pertence á categoría de obxecto ou pertence a categoría de función. Esta ontoloxía responde así ao criterio

\footnotetext{
${ }^{17}$ Cfr. E. Tugendhat, “The Meaning of 'Bedeutung' in Frege”, 1970, pp. 177-189.
} 
sintáctico ou formal utilizado por Frege, que estaba claramente relacionado con nocións matemáticas, especialmente coa de función. O criterio consistía en distinguir o saturado do non saturado, o completo do incompleto, ou o que necesita de complementación do que é autosuficiente. É dicir, as funcións distínguense dos obxectos porque son non-saturadas, incompletas e, posto que presentan lugares baleiros, necesitan ser completadas polo argumento ou argumentos da función, dando lugar ao valor da función para ese argumento (ou argumentos) ${ }^{18}$.

Todo o que non entra dentro da categoría de función é para Frege un obxecto. De feito, a definición do que é un obxecto é negativa e por contraposición á función: "Obxecto é todo o que non é función, a expresión do cal, polo tanto, non leva consigo un lugar baleiro"19. En opinión de Frege o obxecto non permitía unha descomposición lóxica, dada a súa simplicidade, e por iso mesmo non podía ofrecerse unha definición positiva e precisa del. Frege era consciente de que por esta vía admitía "obxectos sen límite como argumentos e como valores de función” ${ }^{20}$ — números, persoas, cidades, países, obxectos en xeral—e de aí, seguramente, a dificultade de ofrecer unha definición uniforme para a inmensa heteroxeneidade de obxectos. O criterio sintáctico, pola contra, é absolutamente simple, posto que reduce o obxecto á categoría de argumento e a aquilo que non admite máis descomposición lóxica, por non ter lugares baleiros que completar. Por iso podería dicirse que a ontoloxía de Frege, ao apoiarse neste criterio formal, lóxico-matemático, estrutura o que hai nas categorías lóxicas de obxecto e función.

Frege estipulou unha gran variedade de obxectos, por exemplo: (i) obxectos reais, como os obxectos espazo-temporais, os cales son obxectos concretos, sensorialmente perceptibles, como as persoas, os animais, os ríos, as cidades, os países, os accidentes xeográficos, os edificios, os planetas, etc; (ii) obxectos abstractos, como sentidos e pensamentos, pero tamén obxectos lóxicos como os valores de verdade e obxectos matemáticos como os números, os cursos de valores das funcións, etc., que son obxectos que non existen no espazo nin no tempo, xa que soen ser eternos, e non son físicos nin mentais; (iii) obxectos mentais, como as representación subxecti-

${ }_{18}$ Obxectos e funcións son para Frege completamente diferentes, e por iso non son substituíbles entre si, ao igual que tampouco poden estar nas mesmas relacións. Así pois, aínda que argumento e función formen un todo completo, o argumento non pertence á función.

${ }^{19}$ G. Frege, "Función y concepto”, Estudios sobre semántica, p. 160.

${ }^{20}$ Ibid. 
vas, os cales son obxectos que non son físicos, polo tanto, que non existen no espazo, e requiren un portador, como os estados mentais ou os datos sensoriais ${ }^{21}$. Esta clasificación dos obxectos levou finalmente a Frege a recoñecer, no seu artigo de 1918 "O pensamento", a necesidade de postular un terceiro reino no que situar aos pensamentos - e por extensión a todas as entidades abstractas-, dada a obxectividade que os caracterizaba e tamén pola imposibilidade de situalos ontoloxicamente tanto no mundo físico como no mental.

En definitiva, podería dicirse que a ontoloxía básica de Frege se orixinou a partir dun criterio sintáctico ou formal. O mesmo criterio de completo / incompleto, ou saturado / insaturado, aplícase ás categorías semánticas e lingüísticas. A aplicación deste criterio ás categorías semánticas que estableceu Frege, a saber, o sentido e a referencia, faise a partir da análise lóxicosintáctica das expresións lingüísticas. A expresións lingüísticas poden ser expresións nominais ou termos singulares (nomes propios, descricións definidas, demostrativos, deícticos, ou mesmo enunciados) e expresións funcionais (expresións predicativas e expresións relacionais, basicamente). As expresións nominais son completas e, por conseguinte, a súa referencia é tamén unha entidade completa, isto é, un obxecto. A expresións funcionais son incompletas e a súa referencia é, polo tanto, unha entidade insaturada, a saber, conceptos e relacións, fundamentalmente. O sentido das expresións nominais tamén é completo, mentres que o sentido das expresións funcionais é incompleto, e, polo tanto, necesitado de saturación.

$\mathrm{O}$ interese de Frege ao introducir esta ontoloxía era poder determinar para as expresións complexas e completas, como os enunciados, o seu valor de verdade, xa que para o coñecemento é imprescindible saber se o seu sentido, isto é, se o que un enunciado expresa, é verdadeiro ou falso. Xa que os enunciados son oracións asertivas e, polo tanto, son expresións complexas

${ }^{21}$ As funcións tamén son de diverso tipo, dependendo dos argumentos que teña a función e do tipo de entidades que ocupan estes argumentos, e tamén dependendo do valor resultante obtido cando a función se satura co seu argumento ou os seus argumentos. Frege distinguiu entre funcións de primeira orde, que son aquelas cuxos argumentos son obxectos, e funcións de segunda orde, que son aquelas cuxos argumentos son funcións. Entre as funcións de primeira orde, as que resultaban máis interesantes a efectos epistémicos eran os conceptos e as relacións, xa que estas eran funcións que, como resultado de completarse cos seus argumentos - un obxecto no caso dos conceptos; e dous, tres ou máis obxectos no caso das relacións-, daban lugar a un valor, que nestas funcións era sempre un valor veritativo, ou ben o verdadeiro ou ben o falso. Hai outras funcións que non son nin conceptos nin relaciones porque non teñen como valor un valor veritativo, senón outro tipo de obxectos, como números ou cidades, como os seguintes exemplos: "x2 + y2", "a capital de x". 
formadas por outras expresións, usualmente nomes propios e expresións predicativas ou relacionais, Frege empregou o principio de composicionalidade para determinar tanto o sentido como a referencia dos enunciados, de tal xeito que o sentido do enunciado, que el denominou "pensamento", era o resultado da composición dos sentidos das expresións que forman o enunciado, e o mesmo era aplicable á referencia. A tese máis importante da semántica de Frege é a afirmación de que a referencia do enunciado é un valor veritativo, a saber, ou ben o verdadeiro ou ben o falso, e para que un enunciado teña un valor de verdade todas as expresións loxicamente relevantes que o forman deberían ter tamén referencia; no caso de que unha expresión do enunciado, usualmente un nome propio, carecera de referencia, entón, non se podía aplicar o principio de composición para a referencia e o enunciado carecía de valor de verdade, tendo unicamente sentido, e sendo irrelevante, en consecuencia, para o ámbito científico.

A partir desta brevísima presentación da semántica e da ontoloxía de Frege pode concluírse que, a pesar de que el recoñecía que para que algo funcionara como signo o importante era que tivera sentido aínda que carecera de referencia, para a análise lóxica e a linguaxe da ciencia o fundamental era considerar só aquelas expresións que tiveran referencia, para así poder ter en conta a súa contribución ao coñecemento, pois só dun enunciado no que todas as expresións tiveran referencia podería dicirse se é verdadeiro ou falso. E esta dimensión da referencia dos signos foi a que máis lle interesou a Frege. Se estamos nun contexto lingüístico serio como é o da ciencia e o do coñecemento científico a referencia dos enunciados, isto é, o seu valor de verdade, vólvese a dimensión máis importante a ter en conta na análise dos signos, pois o que interesa para o coñecemento en xeral é o xuízo, que, como mantén Frege, consiste no paso do sentido á referencia, o paso do expresado por un enunciado á determinación do seu valor veritativo. Pero se o contexto lingüístico cambia e estamos a disfrutar da linguaxe, como cando imos ao teatro, lemos unha obra de ficción, estamos a contar un conto ou unha historia, ou escribimos poesía a referencia dos signos perde todo o seu interese e só nos interesa disfrutar da "iluminación" e o "colorido" —expresións empregadas por Frege— da linguaxe. Por conseguinte, podemos observar que, con respecto á posición mantida por Eco, a de Frege non entra en conflicto coa súa, xa que Frege aceptaría que para que algo sexa signo ten que ter sentido, pero non necesariamente referencia. Porén, situados no campo do coñecemento, a apelación á referencia tórnase fundamental e a necesidade da inclusión do obxecto no modelo explicativo do signo ineludible. 
Pero tamén hai outro aspecto, que por razón de espazo só quedará esbozado, no que a presenza do obxecto no modelo de análise do signo de Frege realiza unha importante función ao estar directamente relacionado co sentido, permitindo a este último cumprir un papel explicativo fundamental na comprensión do funcionamento epistémico do sígnico, en especial na categoría de nomes propios, cuxa referencia é un obxecto. Frege no seu artigo de 1892 "Sobre sentido e referencia", afirma que o sentido dos nomes propios contén a maneira de darse o denotado polo signo ${ }^{22}$, é dicir, contén a maneira na que a referencia, o obxecto, aquilo que o signo denota se presenta ou se dá. Segundo Burge ${ }^{23}$ esta sería a función epistémica que cumpre o sentido na semántica de Frege, pois o signo xa non sería unha mera marca arbitraria, como sucede no caso das abreviaturas, que refire a un obxecto sen achegar sobre el coñecemento algún, ao contrario, para Frege o signo sempre refire ao obxecto a través da mediación do sentido, que proporciona información sobre o mesmo. Por un lado, o sentido do signo, ao recoller aquelas propiedades ou características propias dun obxecto determinado permite obter coñecemento sobre o mesmo, ao tempo que, por outro lado, este mesmo sentido permite determinar a referencia do signo, isto é, permite determinar o obxecto ao que o signo se refire.

En definitiva, na semántica de Frege o obxecto xoga un dobre papel, xa que, por un lado, no seu funcionamento como referencia das expresións é esencial para garantir o valor de verdade dos enunciados e, por outro lado, está relacionado co sentido dos nomes propios, pois o sentido destas expresións contén o modo de darse ou de presentarse a referencia, o obxecto por elas denotado. Desta forma o sentido vólvese a noción explicativa do coñecemento proporcionado polos signos en relación cos obxectos aos que fan referencia. O signo non debe limitarse a ser só un modo de designación, xa que neste caso é posible que non exprese "ningún verdadeiro coñecemento", como diría Frege. Para que un signo exprese ese verdadeiro coñecemento sobre o obxecto é crucial como o signo designa ao obxecto, e esta relación xa non é arbitraria, porque o sentido contén o modo de darse a referencia; aquí, a relación xa é motivada e directamente dependiente de como é a referencia. A referencia é como é, presentándose e manifestándose de múltiples e variadas maneiras, e estes modos diferentes de darse o obxecto son as que expresa o sentido do signo, é como o signo se refire ao obxecto.

\footnotetext{
${ }^{22}$ Cfr. G. Frege, Escritos sobre semántica, p. 173.

${ }^{23}$ Cfr. T. Burge, Truth, Thought, Reason. Essays on Frege, pp. 242-243.
} 


\subsection{O modelo triádico de Peirce. Un modelo dinámico}

No modelo semiótico proposto por Peirce para que algo funcione como signo é requisito indispensable a existencia de tres elementos: representamen ou signo, obxecto e interpretante, que ocupan dende o punto de vista lóxico o lugar dun primeiro, un segundo e un terceiro, respectivamente. Esta referencia ao lugar lóxico dos elementos implicados no proceso de semiose fai preciso traer ao primeiro plano as categorías, isto é, os conceptos máis xerais posibles, nos que Peirce articulou todo o seu pensamento, manifestando o interese filosófico xeral de establecer aqueles conceptos que reducen a multiplicidade das impresións sensibles á unha certa unidade, e seguindo neste caso moi de cerca a liña kantiana da táboa das categorías. Peirce denominou as categorías que el propuxo co nome de categorías "cenopitagóricas", en clara alusión aos pitagóricos pola enorme importancia que estes lle deron aos números. Para Peirce estas categorías son tres e as denominacións máis recorrrentes para elas ao longo de toda a súa produción intelectual son as de "primeiridade", "segundidade" e "terceiridade". Estes nomes son sumamente xenéricos, simples e, en principio, parecen non indicar nada máis que a relación de orde que se establece entre eles, seguindo deste xeito a que para Peirce era a hipótese máis universal, a saber, a dos números. Así, un primeiro non necesita nada máis que de si mesmo para ser; un segundo precisa necesariamente dun primeiro para ser, pois sen a referencia a un primeiro non habería un segundo; e un terceiro é o que establece a relación entre un primeiro e un segundo, neste sentido un terceiro é sempre un mediador. Peirce chega ao convencemento de que a segundidade é inapropiada para abarcar todo o que está na mente e de que é inferior nas súas aplicacións á terceiridade, xa que as combinacións de relacións para formar outras novas son sempre relacións triádicas irreductibles a relacións diádicas. Máis estas categorías remiten a certas ideas fenomenolóxicas, obtidas da experiencia, tales como: cualidade, feito e lei; posibilidade, acción bruta e razón; sensación, existencia e necesidade; idea, realidade e pensamento; ou cualidade, reacción e representación; como resulta evidente, cada unha das ideas destas tríadas se corresponde coa primeiridade, a segundidade e a tercereidade, respectivamente.

Peirce recorre ás categorías para describir en que consiste á representación sígnica: "un signo ou representamen é un primeiro que está nunha relación tríadica xenuína tal cun segundo, chamado o seu obxecto, que é capaz de determinar un terceiro, chamado o seu intepretante, para que asuma a mesma relación triádica co seu obxecto que aquela na que se atopa el mesmo respecto do mesmo obxecto" (CP 2.274) ${ }^{24}$. Para que teña lugar a representación precí-

\footnotetext{
${ }^{24}$ C.S. Peirce, Obra lógico-semiótica, p. 261.
} 
sase, pois, algo do que podamos ter unha sensación ou que teña unha cualidade - un primeiro- que vehicule a referencia a un obxecto - un segundo-e que dea lugar a un interpretante - un terceiro. Nisto consiste el proceso de semiose, o proceso polo cal algo significa ou representa a outra cousa, é dicir, o proceso polo cal algo funciona como signo. Desta descrición que ofrece Peirce hai que destacar que o representamen determina ao interpretante a que asuma a mesma relación triádica na que el mesmo se atopa con respecto ao seu obxecto. Isto é importante porque expresa a condición necesaria para que o interpretante sexa a súa vez signo ou representamen e, polo tanto, dea lugar a unha nova relación de significación ou representación, é dicir, de semiose. Este é un dos aspectos máis novedosos do modelo de análise do signo que presenta Peirce, dotándoo dun dinamismo moi vinculado á importancia que este autor lle deu ao continuo, unha noción encadrada tamén na categoría de terceiridade. $\mathrm{O}$ representamen ao referirse ao seu obxecto xera un interpretante de si mesmo, que non é máis que outro representamen, que volve a referirse ao mesmo obxecto, xerando un novo interpretante, que, potencialmente, pode repetir outra vez esta operación, e así ad infinitum. Así pois, a semiose é un proceso dinámico mediante o cal uns signos remiten continuamente a outros, constituíndo a súa descrición, explicación, definición e, por conseguinte, ampliando, detallando, desenvolvendo, condensando, etc. o representamen do que son interpretantes. Este dinamismo reflectiría a posibilidade de continua referencia duns signos a outros, aínda que efectivamente, no momento de uso do signo, esa semiosis ilimitada non teña lugar.

Mais o dinamismo do modelo triádico de semiose proposto por Peirce está vinculado tamén a súa dimensión formal, xa que para que algo sexa signo, obxecto ou interpretante hai que ter presente a posición lóxica que cada un destes elementos ocupa na semiose. Así, o obxecto do signo pode ser calquera obxecto que determina ao signo a representalo dunha certa maneira. Dito doutro xeito, o que nunha semiose funcionaba como un primeiro - un representamen ou signo- pode noutra semiose funcionar como un segundo -un obxecto-, ou noutra semiose ocupar o lugar dun terceiro - un interpretante, co cal calquera cousa que funciona como signo ou primeiro, pode noutro momento semiótico funcionar como obxecto da semiose ou segundo, o como interpretante ou terceiro. En conclusión, ser signo, obxecto ou interpretante depende da posición lóxica que ocupan cada un dos elementos da semiose, na súa condición de primeiro, segundo ou terceiro. Segundo Peirce, para que se dea unha relación semiótica xenuína estes tres elementos deben estar sempre presentes, xa que calquera cousa pode funcionar como signo, sempre que xere un proceso de referencia a un obxecto por medio do cal se determina un interpretante. 
Con respecto ao papel que xoga o obxecto na semiose, Peirce distingue dous obxectos do signo: o obxecto dinámico e o obxecto inmediato. O primeiro - denominado tamén obxecto mediato-, é o obxecto exterior ao signo, entendido como a realidade extralingüística á que o signo se refire, así describe Peirce o obxecto dinámico: "a realidade que dalgunha maneira contribúe a determinar ao signo para a súa representación” (CP 4.536) O obxecto inmediato é o obxecto interior ao signo, o obxecto tal e como é representado polo signo; neste sentido, e segundo Peirce, o ser do obxecto inmediato depende da súa representación no signo ${ }^{26}$. Destas caracterizacións do obxecto parece desprenderse que para Peirce a relación entre o signo e o obxecto é, nalgún sentido, motivada, xerada ou determinada polo obxecto dinámico. $\mathrm{O}$ efecto desta contribución da realidade no proceso de significación plásmase no obxecto inmediato. Da relación entre o signo e o obxecto xurde o interpretante. O interpretante, en tanto terceiridade, é o elemento que establece a mediación entre o signo e o obxecto. Deste xeito, o interpretante pode identificarse co obxecto inmediato, pero non unicamente, pois a noción de interpretante en Peirce é moi amplia, como queda patente a través da distinción de varios tipos de interpretante: o inmediato, o dinámico e o final ${ }^{27}$. O signo sen un interpretante non sería máis que un significante.

${ }^{25}$ Ibid., p. 381.

${ }^{26}$ En textos como o de 1867 — cando Peirce contaba 28 anos- titulado "Dunha nova lista de categorías", Peirce fala tamén do "fundamento" do signo. Neste artigo o fundamento parece corresponderse coa categoría de primeiridade, ao presentalo como unha cualidade ou unha abstracción, isto é, como un primeiro, aínda que noutro momento do texto Peirce parece identificalo tamén co interpretante, destacando entón o seu carácter mediador. Así pois, xa dende o comezo da súa reflexión sobre o signo está presente a idea dunha orde relevante que establece o lugar lóxico que cada elemento ocupa na semiose, pois o fundamento é un primeiro cando é unha cualidade, que no proceso de semiose é un signo ou representamen, que representa ao obxecto dinámico nalgún aspecto, determinado polo propio obxecto. Mais, o fundamento tamén pode entenderse como unha categoría mediadora, como un interpretante, e así é aquilo que o signo determina na súa referencia ao obxecto, xa que o signo se refire ao obxecto nalgún aspecto ou capacidade. Deste xeito resulta factible a explicación de como o interpretante é a súa vez un representamen, isto é, un terceiro que se convirte en primeiro, para referirse ao mesmo obxecto e da mesma maneira xeradora dunha nova semiose.

${ }^{27} \mathrm{O}$ interpretante final é un terceiro, que representaría a culminación do proceso de semiose e mostraría o efecto pleno e total do signo. O interpretante dinámico é un segundo, un evento singular e real, relativo aos efectos directos realmente producidos polo signo e experimentados en cada acto de semiose. O interpretante inmediato é un primeiro, unha abstracción, unha posibilidade, e consiste na interpretabilidade propia de cada signo, ainda cando este non teña un intérprete concreto. O interpretante inmediato sería, pois, equiparable ao obxecto inmediato, ao obxecto tal e como o signo o representa; isto é, á interpretabilidade propia e característica de cada signo na súa referencia ou aplicabilidade ao obxecto. 
É precisamente pola relación que o signo establece cun obxecto, pola súa capacidade de referise a un obxecto, isto é, de estar no seu lugar, a que produce que o signo signifique algo e, neste sentido, que xere un interpretante.

Para Peirce, a semiótica é a ciencia que estuda os elementos presente na semiose e as relacións que se dan entre eles. Peirce concibía a semiótica como lóxica en sentido amplo, xa que a lóxica, como era tradicionalmente entendida, viña a corresponder con aquela parte da semiótica que el denominou "lóxica exacta" e que definiu como a doutrina das condicións formais da verdade dos símbolos, o que dito noutros termos, é a doutrina da referencia dos símbolos ós seus obxectos. Para Peirce, esta é unha forma moi restrinxida e parcial de entender a lóxica, pois así concibida esta lóxica equivale á semántica extensional ou referencial. Pola contra, a lóxica entendida como semiótica estudaría as leis e condicións xerais dos signos ou, noutras palabras, sería a ciencia das leis necesarias do pensamento. A partir desta concepción da lóxica como semiótica o ámbito de estudo da lóxica amplíase, pois xa non se centra na análise das relacións entre un tipo de signo, a saber, os símbolos e os seus obxectos, senón tamén das relacións entre estes e os seus interpretantes; e xa non só se ocupará dun tipo particular de signo, como é o símbolo, senón de todo tipo de signos, incluíndo tamén a iconos ou índices, presentes en moitos argumentos e razoamentos. A partir do modelo triádico de semiose proposto por Peirce, a semiótica dividese en tres ramas: gramática especulativa, lóxica exacta e retórica pura, que abordaban, respectivamente, a análise dos representámenes, as relacións entre os representámenes e os seus obxectos, e as relacións entre os representámenes e os seus interpretantes ${ }^{28}$. Deste xeito conseguese unha análise completa e xeral de todas as dimensións implicadas na semiose.

\section{Conclusións}

Todos os autores aquí presentados, tanto semióticos como filósofos analíticos, coinciden en que un signo para ser tal ten que significar algo, ten que ser algo máis que unha marca, un trazo no papel ou un son articulado.

${ }^{28}$ Porén, a división da semiótica máis recoñecida non é esta, proposta polo seu fundador, senón a que articulou Morris, na que a semiótica tiña tres ramas, a saber, a sintaxe, a semántica e a pragmática. A diferenza de Peirce, a pragmática de Morris ocupábase das relacións entre o vehículo sígnico e os intérpretes, isto é, os usuarios e usuarias de signos. O modelo de semiose de Peirce obviaba o intérprete, xa que quería explicar o funcionamento sígnico nos seus propios termos, de xeito cuasi-formal, sen recorrer as complexidades que, obviamente, introducía o intérprete ou usuario de signos. 
Así pois, a relación semántica fundamental, tal e como subliñaron todos eles, é a que se establece entre signo e significado (Saussure), entre o funtivo da expresión e o funtivo do contido (Eco), entre signo e sentido (Frege) ou entre signo e interpretante (Peirce). Tanto para Saussure como para Eco o modelo diádico do signo daba conta desta relación esencial que constitúe ao signo e, ademais, ambos os dous destacaron o papel que xoga a sociedade e a cultura na determinación do significado. Dende esta perspectiva o rol do obxecto non era absolutamente imprescindible para explicar o funcionamento sígnico, aínda que neste modelo si que aparecían certos problemas á hora de abordar o funcionamento dos termos singulares, como nomes propios ou descricións definidas, expresiónss tipicamente referenciais, nas que a referencia ao obxecto denotado parece ineludible; ou tamén para dar conta da contribución destas expresións ao valor veritativo dos enunciados. Inicialmente, Eco excluiu da semiótica o estudo das relacións referenciais e extensionais do signo, pola limitación que supoñían para unha concepción máis ampla de signo que permitira tratar semioticamente expresións carentes de referencia, máis, finalmente, foi quen de atoparlle un lugar no ámbito semiótico ao situalas na semiótica da comunicación. Deste xeito a semiótica pode estudar todo tipo de signos, sexan estes referenciais ou non.

Á diferenza de Saussure e Eco, tanto Frege como Peirce prestaron unha gran atención ao obxecto. $\mathrm{O}$ obxecto enténdese como un elemento estreitamente vinculado ao sentido do signo (Frege) ou xerador do seu interpretante (Peirce). Ademais, o sentido ou o interpretante funcionan como elementos mediadores na relación signo / referencia ou signo / obxecto, ao tempo que actúan como nocións explicativas do valor cognoscitivo do signo. Para Frege, o sentido dun signo contén o modo de darse a referencia; e, para Peirce, o obxecto determina ao signo a que o represente dunha certa maneira, e esa forma de representar o signo ao seu obxecto é o interpretante. É dicir, o sentido e o interpretante están mediando entre o signo e o obxecto, ou entre o signo e a referencia, de tal forma que o obxecto ten unha certa capacidade determinadora de como o signo vai a referirse a el. De aquí pode concluírse que o sentido ou o interpretante do signo non son meras decisións arbitrarias o convencionais, senón que están forzados polo obxecto a concordar na descrición do mesmo coas propiedades que este presenta.

Como xa se indicou, tanto Frege como Peirce eran lóxicos, e concibiron o estudo do signo en estreita relación coa lóxica. A análise da linguaxe natural que leva a cabo Frege está directamente vinculada cos seus intereses lóxicos. A distinción entre sentido e referencia e a caracterización destas nocións para nomes propios, expresións predicativas e asercións pon de 
relevo este feito, pois, como xa veu, a referencia dun enunciado é un valor de verdade. Se un nome propio que aparece nun enunciado non ten referencia, tampouco a terá o enunciado do que forma parte e, por conseguinte, carecerá de valor veritativo, pasando así a ser irrelevante para a ciencia ou o coñecemento en xeral. É interesante destacar tamén que tanto no caso de Peirce como no de Frege son as súas investigacións lóxicas as que os levan a ir máis alá da relación lóxica fundamental —a de denotar ou referir- para abordar o estudo doutra relación semántica básica: a de significar, e así as nocións de sentido, en Frege, e de interpretante, en Peirce, son introducidas para explicar esta relación. Polo tanto, o modelo triádico amósase máis completo e explicativo que o diádico, xa que pode dar conta do funcionamento do signo, tanto cando este refire a obxectos, como cando este non é o caso, se ben para os autores que propuxeron este tipo de modelo, o funcionamento ideal e xenuíno do signo debe implicar sempre aos tres elementos en xogo.

\section{Bibliografía}

Barthes, R.: Elementos de semiología, Alberto Corazón, Madrid, 1971.

Burge, T.: Truth, Thought, Reason. Essays on Frege, Clarendon Press, Oxford, 2005. https://doi.org/10.1093/acprof:oso/9780199278534.001.0001

Domínguez Rey, A.: Masaje del mensaje, Torre Manrique Publicaciones, Madrid, 1988.

Eco, U.: La estructura ausente, Lumen, Barcelona, 1978.

Eco, U.: Signo, Labor, Barcelona, 1980 (Edición original: 1973).

Eco, U.: Tratado de semiótica general, Lumen, Barcelona, 1981.

Eco, U.: "Meaning and Denotation", Synthese, 1987, pp. 549-568. https://doi.org/10.1007/BF00484992

Eco, U.: Semiótica y filosofía del lenguaje, Lumen, Barcelona, 1990.

Frege, G.: Funktion, Begriff, Bedeutung, Vandenhoeck \& Ruprecht, Göttingen, 1980.

Frege, G.: Estudios sobre semántica, Crítica, Barcelona, 1996.

Frege, G.: Investigaciones lógicas, Tecnos, Madrid, 1984.

Morris, C.: Fundamentos de la teoría de los signos, Paidós Comunicación, Barcelona, 1985.

Peirce, C.S.: Collected Papers of Charles Sanders Peirce, C. Hartshorne, P. Weiss e A. W. Burks (eds.), Harvard University Press, Cambridge, Mass., 1931-1958 (8 vols.). 
Peirce, C.S.: Obra lógico-semiótica, Taurus, Madrid, 1987.

Saussure, F. de: Curso de lingüística general, Akal, Madrid, 1980.

Tugendhat, E.: “The Meaning of 'Bedeutung' in Frege”, Analysis, 1970, pp. 177-189. https://doi.org/10.1093/analys/30.6.177 